European Fiscal Policy Coordination and the Persistent Myth of Stabilization

\author{
Erik Jones \\ SAIS Bologna Center \\ via Belmeloro 11 \\ 40126 Bologna \\ ITALY \\ ejones@jhubc.it
}

(Very) Preliminary draft - comments welcome

draft date: 17 May 2007

EUSA Tenth Biennial International Conference

Montreal, Canada * May 17-May 19, 2007

Panel 9B: EU Macroeconomic Governance - Past Lessons and Future Directions

Saturday, May 19, 2007 (0830-1015) 


\title{
European Fiscal Policy Coordination and the Persistent Myth of Stabilization
}

\author{
Erik Jones \\ SAIS Bologna Center
}

The asymmetric constitution of European macroeconomic governance is well known. Monetary policy is made at the European level, while fiscal policy remains the purview of the member states. The pathologies this creates are also well known. Macroeconomic policy is uncoordinated at the European level and fiscal policy is uncoordinated across the member states. The result is almost universally regarded as sub-optimal (Tsoukalis 2005: 161). Better coordination of monetary and fiscal policy at the European level could improve aggregate demand management for those countries that have adopted the euro taken as a group (the euro-zone). Better coordination of national fiscal policies could also enhance predictability (and reduce negative externalities) in a context of high interdependence and so improve national achievement of national objectives with national fiscal instruments. Alas, the prospects for better coordination are slim.

The prospects for a first-best alternative-the creation of common European fiscal institutions-are even slimmer. Despite repeated calls (particularly in France) for the creation of a fiscal counterpart to the European Central Bank, the willingness of the member states to transfer significant tax authority to the European Union is virtually non-existent. Even more modest proposals to create thin fiscal institutions designed to stabilize income performance across member states have little support (Tsoukalis 2005: 155). Moreover, the stakes are high. As Paul De Grauwe (2006: 728) explains: 'It is difficult to conceive how a union can be politically sustainable if each time a country of the union gets into trouble because of asymmetric developments, it is told by the other members that it is entirely its own fault and that it should not count on any help. Such a union will not last.'

Of course, this two-paragraph summary of the conventional wisdom hinges on the phrase: almost universally regarded. There are policymakers and economists who do not support such a grim view of European macroeconomic governance. Most of them live and work in Brussels and Frankfurt. That geographic location is a disadvantage, if only because it suggests a strong, institutional self-interest in perpetuating (or at least justifying) the status quo. Attempts to unite these voices in a 'Brussels-Frankfurt consensus' in loose parallel with the old 'Washington consensus’ only make matters worse (De Grauwe 2006: 724-727, Tamborini 2006). There is nothing more disconcerting than the threat of ideological condominium.

Institutional and ideological influences are not as important as they might seem at first glance. Seen from Bologna, there are good reasons to doubt the mainstream critique of European macroeconomic governance. Probably the most important is the bias in the conventional wisdom against diversity, asymmetry, inequality, and difference. A close second is the weak scrutiny of realistic alternatives. It may be possible to make macroeconomic governance better it Europe, but the reverse is also true. We should be sure that what we have is broken before we try to fix it.

The purpose of this paper is to present an alternative view. It is not a comprehensive argument. Rather it is a piecemeal attack on three of the building blocks in the conventional wisdom. Specifically, I am interested to examine the relationship between stabilization and adjustment; the prospects for fiscal stabilization; and the idea of international fiscal stabilization-by which I mean the timely transfer of fiscal resources to offset asymmetric economic performance across national economies within a common currency area like the euro-zone. My contention is that if we took a different view on these issues, we would find it hard to sustain the conventional wisdom and easy to see how suggestions for closer macroeconomic and fiscal policy coordination are likely to make matters worse. 


\section{Stabilization and Adjustment}

At its heart, the economic debate about national currencies, common currencies, and optimum currency areas hinges on the problem of shocks and adjustment. The trick is to make sure that unemployment levels do not rise (or endure) every time something bad happens and the national economy suffers from an adverse shock. This debate assumes that price (and wage) adjustments are neither smooth nor automatic. If prices and wages adjusted smoothly and automatically in response to economic shocks, there would be little or no debate about optimum currency areas because there would be no connection between money and unemployment. As it is, prices do not adjust automatically or smoothly. Therefore, adjustments are more likely to take place in terms of quantities than in terms of prices-and the adjustments we are most concerned about are measured in terms of the quantity of labor.

National currencies and exchange rates enter into the debate about shocks and adjustment in two ways: through relative prices; and through macroeconomic policy instruments. The relative price mechanism is the easiest to explain. If, for example, foreign demand declines for a country's major exports, then a depreciation of the currency could stimulate foreign demand and switch domestic spending by changing the relative price of foreign and domestic goods. In other words, the flexibility of exchange rates can replace the rigidity of domestic prices. The macroeconomic policy flexibility is a bit more complicated. If foreign demand declines for a country's major exports, then a timely reduction in domestic interest rates could stimulate investment and consumption to compensate for the decline in output. The problem is that such a monetary policy change is not possible under conditions of fixed exchange rates and international capital mobility. Any reduction in relative nominal interest rates will spark capital movements out of the country to take advantage of higher yields elsewhere, drawing down on the foreign exchange reserves of the central bank and ultimately (if not immediately) bringing down the exchange rate peg as well. In a fully fledged monetary union there is no recourse to national monetary policy at all-because interest rates are set at union level. Either way, domestic monetary autonomy and the demand stabilization that it promises are lost as a result.

These features of national currencies-relative price flexibility and macroeconomic policy autonomy-are well known and often described in the literature. The assumptions that underpin them are less prominent. For example, commitment to flexible exchange rates rests on four assumptions:

* $\quad$ exchange rate determination takes place in the goods market;

* $\quad$ aggregate trade and industry data reflects conditions for individual firms and markets;

* $\quad$ bilateral exchange rates move independently;

* the exchange rate policy choices of other countries are the same as those taken at home.

If exchange rate determination does not take place in the goods market, then exchange rate changes will not move mechanically to mitigate exogenous shocks like a fall in foreign demand. Export demand will fall, but the exchange rate will not depreciate as a result. This is likely to be the case when international capital flows are more important in the balance of payments than international trade flows-as they are today. That explains why countries experience prolonged deviations from balance on their current accounts. And while it may be true that such current account imbalances have to be rectified in the long-run, that truism tells us very little about the usefulness of exchange rates in preventing unnecessary unemployment when an adverse shock takes place (Tavlas 1993: 678-679). Hence it is not surprising that economics commentators in policy journals would suggest we need fewer national currencies (Steil 2007).

The assumption about aggregate data and individual firms and markets is a reference to the ecological fallacy. In the context of unemployment and exchange rates, there are many ways that 
this fallacy can be revealed. To begin with, the value structure of foreign trade may not reflect its employment content. This was the case for Ireland in the early 1990s (Kavanagh et al. 1998: 135). As demand increased for high-value Irish exports to the European Continent, the Irish pound appreciated against the British pound and cut into the profitability of high-employment exports from Ireland to the UK. Given the strength of the Irish economy overall, this unemployment in traditional industries proved not to be a problem. Still the point is that exchange rate movements added to rather than mitigating the pressures for adjustment.

A second version of the ecological fallacy is that a given country's predominant exports are not predominant in all export markets and individual exporters are potentially market-specialized as well. Such firm and market specialization is characteristic of trade resulting from scale economies including manufacturing processes and product lines that are distributed across different foreign subsidiaries of the same national firm-a point that has been underscored by Gowa and Mansfield (2004: 779-781). The implication is that a general fall in demand for a particular export will have greater exchange rate implications with some trading partners than with others and that the beneficial effects of any resulting exchange rate movements could be firm-specific as well. Otmar Issing tells the story of his encounter with an Austrian machine tool manufacturer in the early 1990s who claimed he was ruined by Germany’s tight monetary policy and Italy's subsequent exit from the exchange rate mechanism (ERM). Of course with the law of large numbers, such anecdotes tend to iron out. Nevertheless, the implication is that such ironing out takes place through movements in the labor market and it is precisely these movements that exchange rates are meant to mitigate if not to prevent.

The assumption about the independence of bilateral exchange rates is a modeling convention. Usually, economists model arguments about exchange rates in terms of two-county dyads: Country A and Country B or, to borrow from Robert Mundell (1973: 116), Capricorn and Cancer. When they generalize from these models, the assumption is that there is no link between any two dyadic pairs. In essence, the exchange rate between the British pound and the euro is independent of the exchange rate between the pound and the dollar. Of course this is obviously not the case. The pound/euro and the pound/dollar are connected via the euro/dollar exchange rate. Nevertheless modeling that connection presents a significant complexity for the argument about exchange rate stabilization. If the euro/dollar exchange rate moves in response to an exogenous shock, then either the pound/dollar or the pound/euro exchange rate must change as well.

Reference to trade-weighted or 'effective' exchange rates do not eliminate this problem. However much they moves against either currency, pound exchange rates become the source of the exogenous shock for the British economy, not the response. Figure 1 should have the pound has been whip-sawed by the euro-dollar relationship since the start of the single currency in 1999 . These exchange rate movements are the cause of shocks in the British economy, not the response. On 17 May 2007, the Financial Times ran an editorial celebrating that exchange rates movements such as these had finally crushed traditional British manufacturing and ushered in a predominantly service-sector economy. It is hard to believe (even if true) that they were not being ironic.

\section{Insert Figure 1 about here.}

A tighter focus on exchange rate volatility as opposed to changes does not solve the problem of independence either. This point is worth dwelling on because a number of authors have tried to explain dyadic exchange rate volatility either as a function of optimum currency area indicators (Bayoumi and Eichengreen 1997, 1998) or as the 'cost' of monetary integration (Sadeh 2005, 2006a, 2006b). By putting exchange rate volatility-measured as the standard deviation of first-order log changes-on the left-hand side of the equation, they make a strong commitment to the assumption of dyadic exchange rate independence. This is possible, as Bayoumi and Eichengreen (1997: 764; 1998: 202) suggest, because: 'while it is true that changes in bilateral rates are not independent . . . the standard deviations of these rates are independent as the 
Figure 1: The British Pound Since EMU

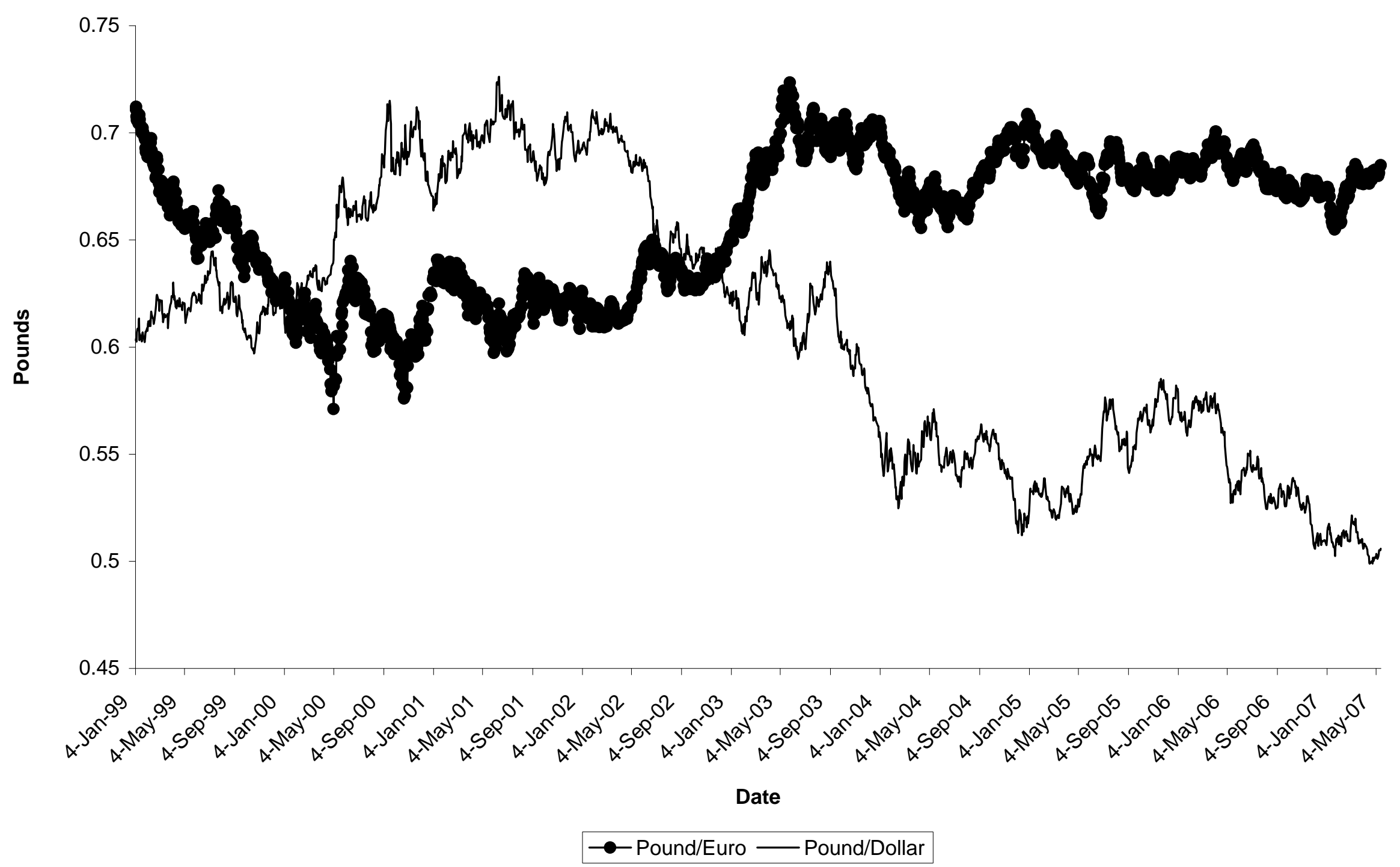


covariances can differ across pairs of countries.' They may have a point. Nevertheless, from an algebraic perspective, it is hard to see how the standard deviations of dyadic pairs can be independent when the formula for the covariance of any one exchange rate dyad (euro/pound) can be written exclusively in terms of two others (euro/dollar; pound/dollar). From an empirical perspective, it is relatively easy to demonstrate that the standard deviations of first-order log changes are highly correlated from one set of national currency dyads to the next. Table 1 provides the cross correlation in volatility measures among those countries participating in the European Union's exchange rate mechanism (ERM) from 1991 to 1998. With the exception of Italian (and the partial exception of Finland), the correlations are all strong. Indeed, many are very close to 1.

Insert Table 1 about here.

Of course Bayoumi and Eichengreen are right to assert that the covariances can differ. The point is that they do not have to differ and there are good reasons why they would not differ. Where one market and one currency predominate in regional trading arrangements, we should expect any shocks to that market and that currency to propagate outward across the regional exchange rate system as a whole. Such propagation is even more likely when other countries peg their currency values on the regional core. This is why the ERM country dyads are highly correlated and it is where the fourth assumption that other countries' choice of exchange rate policy is the same as the home country comes into play. As Peter Kenen (1969: 53) stresses, it is no use telling the home country to opt for flexible exchange rates while other countries prefer to fix: 'How many times have we to remind our students-and ourselves as well-that an exchange rate is common to two countries, not the exclusive national property of one or the other?'

Further illustration of this problem of foreign country exchange rate preferences can be seen in the current debate about 'global imbalances'. The Chinese government intervenes in currency markets to stabilize the value of the yuan/renminbi against the dollar despite a widening trade surplus with the United States. Meanwhile, the dollar depreciates against the euro although trade relations between the United States and eurozone economies are relatively close to balance. Another example could be Lithuania. When the Lithuanian government switched its currency peg from the dollar to the euro in February 2002, it switched its pattern of exchange rate volatility from the dollar to the euro as well. Finally, we can connect the two stories by looking at the relationship between dollar volatility and euro volatility. The Chinese decision to peg on the dollar has shifted the bulk of any exchange rate turbulence resulting from the U.S. current account deficit onto the euro/dollar relationship. In turn this turbulence has spread outward onto third currencies whose governments choose to peg on either the euro or the dollar. Hence it is possible for country dyads to be correlated even outside of a formal system like the ERM. Table 2 provides data for the standard deviation in day-to-day log changes in third country exchange rates against both the euro and the dollar from January 1999 to March 2005. It also includes entries for the dollar against the euro and the euro against the dollar. Omitting the euro and dollar entries, the coefficient of correlation between the two columns is 0.56 .

Insert Table 2 about here.

This brings us to the question of monetary policy autonomy. Here the focus of the debate is on the possibility that a common monetary policy will not be right for any given member state-or, as Henrik Enderlein puts it, the problem that the ECB provides a monetary policy for a country that does not exist. The debate hinges on two observations: one concerns nominal interest rate convergence and the other concerns inflation and therefore real-interest rate divergence. The basic picture can be seen in Figure 2, which plots the standard deviation across national long-term nominal interest rates together with the standard deviation across national inflation rates. The first point to note in the figure is the relative magnitudes of the primary and secondary y-axes.

Measured in basis points, the standard deviation across inflation rates is approximately eight times greater than the standard deviation across long-term nominal interest rates. A second point is that while the two measures are correlated, the coefficient of correlation (0.51) is less than one. 
Table 1: Volatility and Correlation among ERM Currencies, 1991-1998.

\begin{tabular}{|c|c|c|c|c|c|c|c|c|c|c|c|}
\hline & Guilder & B Frank & Mark & Drachma & Peseta & Fr Franc & I Pound & Lire & Schilling & Escudo & Maarkka \\
\hline Dutch Guilder & 1.00 & & & & & & & & & & \\
\hline Belgian Frank & 0.98 & 1.00 & & & & & & & & & \\
\hline German Mark & 1.00 & 0.97 & 1.00 & & & & & & & & \\
\hline Greek Drachma & 0.93 & 0.97 & 0.92 & 1.00 & & & & & & & \\
\hline Spanish Peseta & 0.76 & 0.83 & 0.76 & 0.91 & 1.00 & & & & & & \\
\hline French Franc & 0.96 & 0.99 & 0.96 & 0.99 & 0.86 & 1.00 & & & & & \\
\hline Irish Pound & 0.88 & 0.95 & 0.88 & 0.98 & 0.92 & 0.98 & 1.00 & & & & \\
\hline Italian Lire & -0.54 & -0.47 & -0.55 & -0.25 & 0.00 & -0.45 & -0.21 & 1.00 & & & \\
\hline Austrian Schilling & 1.00 & 0.97 & 1.00 & 0.92 & 0.76 & 0.96 & 0.88 & -0.55 & 1.00 & & \\
\hline Portuguese Escudo & 0.88 & 0.92 & 0.87 & 0.96 & 0.94 & 0.95 & 0.96 & -0.15 & 0.87 & 1.00 & \\
\hline Finnish Maarkka & 0.38 & 0.45 & 0.37 & 0.56 & 0.74 & 0.52 & 0.78 & -0.03 & 0.37 & 0.64 & 1.00 \\
\hline
\end{tabular}

Note: Volatility is measured as standard deviation of day-to-day log changes in bilateral exchange rates, the correlations are across country dyads. Data Source: DNB. 
Table 2: Euro and dollar exchange rate volatility, 1999-2005.

$\begin{array}{lrr}\text { Dollar or Euro } & 13.4 & 13.0 \\ \text { Japanse yen * } & 11.1 & 6.9 \\ \text { Tsjechische koruna * } & 7.0 & 16.1 \\ \text { Deense kroon * } & 0.2 & 13.0 \\ \text { Estlandse kroon * } & 0.0 & 13.0 \\ \text { Cypriotisch pond * } & 0.8 & 12.4 \\ \text { Letlandse lat * } & 7.6 & 5.8 \\ \text { Litouwse litas * } & 8.4 & 14.8 \\ \text { Maltese lira * } & 2.9 & 10.2 \\ \text { Hongaarse forint * } & 3.1 & 13.8 \\ \text { Poolse zloty * } & 8.2 & 7.9 \\ \text { Sloveense tolar * } & 7.2 & 11.8 \\ \text { Slowaakse koruna * } & 4.0 & 15.4 \\ \text { Zweedse kroon * } & 3.4 & 13.0 \\ \text { Britse pond * } & 5.2 & 8.7 \\ \text { Bulgaarse lev * } & 0.2 & 13.3 \\ \text { Roemeense leu * } & 30.9 & 24.8 \\ \text { Nieuwe Turkse lira 2) * } & 45.2 & 40.4 \\ \text { Noorse kroon * } & 4.2 & 11.9 \\ \text { IJslandse kroon * } & 7.7 & 14.3 \\ \text { Zwitserse frank * } & 3.1 & 12.2 \\ \text { Canadese dollar * } & 7.5 & 7.4 \\ \text { Australische dollar * } & 4.7 & 13.2 \\ \text { Nieuw-Zeelandse dollar * } & 5.1 & 16.9 \\ \text { Singaporese dollar * } & 11.4 & 3.0 \\ \text { Hongkongse dollar * } & 13.3 & 0.2 \\ \text { Zuid-Koreaanse won * } & 10.8 & 5.9 \\ \text { Mexicaanse peso } & 21.1 & 8.1 \\ \text { Zuid-Afrikaanse rand * } & 16.4 & 21.3 \\ \text { Taiwanese dollar } & 13.9 & 4.1 \\ & & \\ \text { Correlation (omitting Euro/Dollar) } & & 0.56 \\ & & \end{array}$

Note: volatility is standard deviation of day-to-day log changes.

Data source: DNB. 
Changes in the dispersion of national inflation rates do not translate wholly into changes in the dispersion of national long-term interest rates. As a result, changes in national inflation rates promote changes in national measures for long-term real interest rates.

\section{Insert Figure 2 about here.}

These data raise concern that the common monetary policy may have a strong pro-cyclical bias within the member states. Countries with relatively fast growth and high rates of inflation will face low real interest rates while countries with relatively slow growth and low rates of inflation will face high real interest rates. As a consequence, the common monetary policy will slow the pace of borrowing for investment and consumption where it is most needed and raise the pace of borrowing where it is not (Enderlein 2006: 114, Goodhart 2006: 772).

The assumption here is that borrowers and lenders perceive real interest rates differently. Lenders look at interest rates across the eurozone as a whole. Hence their willingness to enter into national markets or national financial instruments does not depend upon inflation differentials and is instead only a function of relative liquidity and default risk. Because these risks are very small, at least in the sovereign debt market, nominal interest rate differentials across euro-zone countries are small as well. The widest range recorded in monthly data for long-term nominal interest rates across sovereign borrowers in the euro-zone between January 2001 and May 2006 was just 83 basis points, the tightest was 18 , and the average range was 39. Since lenders who ignore national inflation rate differentials are implicitly using a common price deflator, these differences in nominal interest rates measure the difference in real interest rates as well.

This perception of real interest rates is not the same on the other side of credit markets-or so the assumption runs. People who borrow do not use a common measure of inflation to calculate real interest rates. Instead, they deflate nominal interest rates with national price indexes. Hence, for borrowers, the range of experience is much larger. Using the same monthly data, the greatest dispersion in national real interest rates ranged by 357 basis points, the tightest ranged by 223, and the average dispersion was 299 basis points (or roughly 3 percent). These numbers are very large and yet they must have been invisible to lenders otherwise it would be hard to explain why anyone would lend money in countries like Ireland (where real interest rates are often negative) instead of Germany or Austria (where they are strongly positive). Given the tightness of nominal interest rate differentials, it is clear that differences in real interest rates deflated by national price indexes do not matter to lenders.

The assumption that lenders and borrowers perceive different real interest rates is not so strange as it sounds. Banks and other financial institutions usually care more about the rate of intermediation-meaning the difference between borrowing costs and lending rates within a fixed risk category-than they care about price-deflated real interest rates per se. This explains why banks continue to lend even when nominal interest rates fall below the rate of inflation and national real interest rates are negative. Likewise it is obvious that firms and other domestic actors would take local inflation rates into account when making their investment decisions. What is less obvious is how domestic actors are using domestic inflation rates in their discounting.

To understand this point it is necessary to consider the microeconomic foundations for the influence of real interest rates on investment. The standard notion is that the real interest rate represents the cost of borrowing or the opportunity cost of foregoing a financial investment in order to purchase plant, equipment, or other capital goods. But firms do not base their investment decisions solely on financial cost. Returns are important as well. Hence firms have to come up with business models within which the cost of investment and the cost of doing business are covered by future revenues. In these calculations, real interest rates are important only in terms of opportunity costs in comparing the rate of return from the business model with the alternative of the firm investing in financial instruments. The real or price-deflated cost of borrowing does not enter into business models themselves because the nominal cost of repayment is included along with the 
Figure 2: Variation in Eurozone Long-term Interest Rates and Monthly HICP

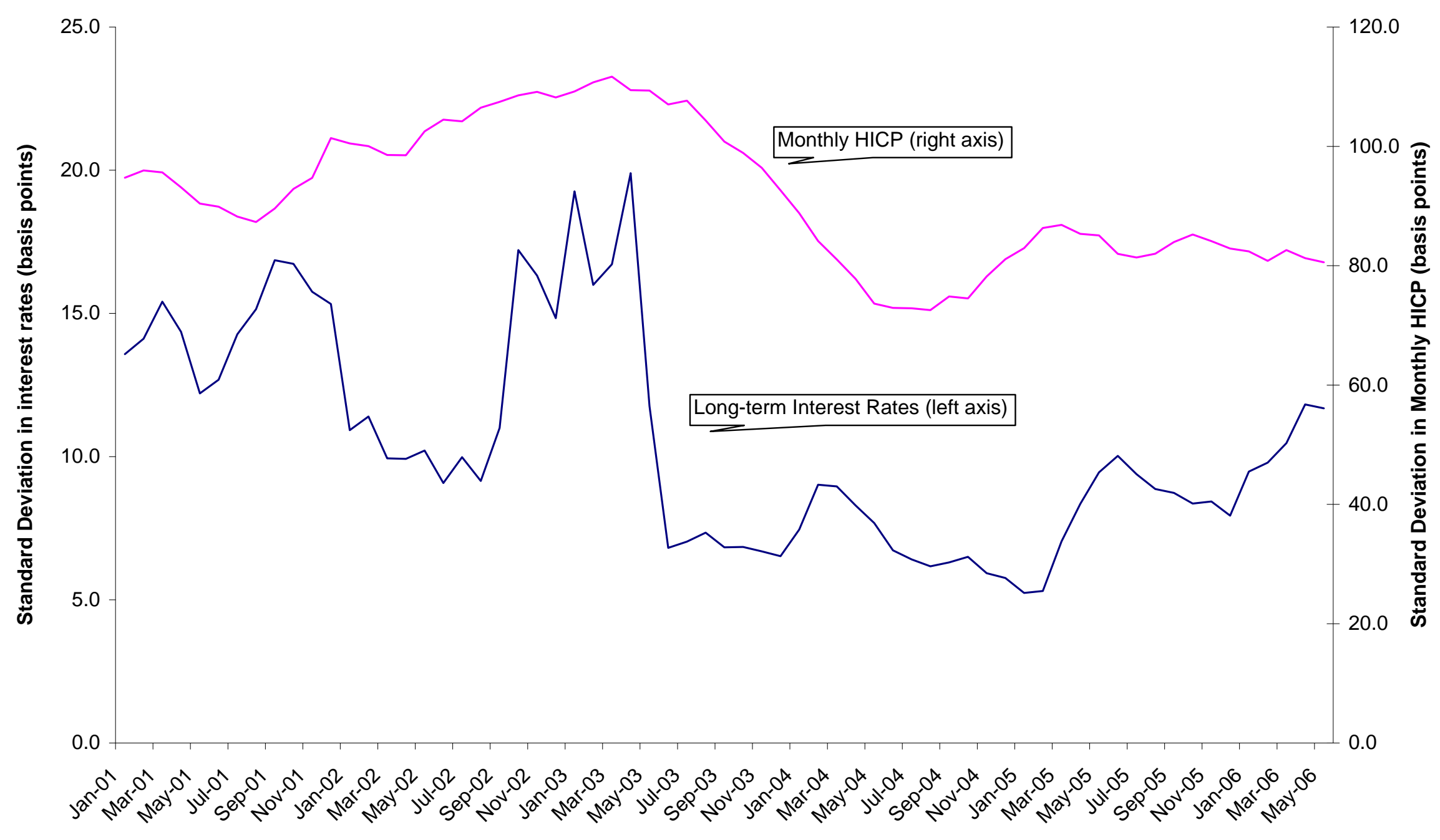


other costs of doing business as a whole.

This is where the micro-foundations of the investment function get tricky. For a domestic manufacturer, operating costs are local but revenues are earned both at home and abroad. Labor costs are doubly local because labor does not move (and so cannot be arbitraged) and because trade unions take local rates of inflation into account in wage bargaining. Hence, while local costs may differ significantly from one production site (and one member state) to the next, manufacturing prices can be arbitraged across the monetary union as a whole and so should be roughly the same. In this context, it is reasonable for firms in traded goods industries to use domestic inflation rates to anticipate the rise in local production costs-including, particularly, labor costs-and international inflation rates (in traded goods prices) to calculate future earnings.

The implication is that net nominal returns from a capital investment made in a highinflation environment will be lower than net nominal returns from the same investment made in a low-inflation environment. This comparison of net nominal returns is important for firms choosing between making similar investments in different parts of the monetary union. Moreover, such firms are unlikely to use different price deflators for different countries because they will compare both possible investments to a single opportunity cost. Like other international lenders, they will calculate relative real returns using a price deflator that applies to the monetary union as a whole. Financial industries may be focused on the rate of intermediation, but both lenders and borrowers are seeing the same real interest rates.

There are two exceptions to this argument: service industries that are not traded internationally and the housing market. Exclusively domestic service industries would be right focus on national price deflators for discounting both nominal interest rates and returns on investment. Even so, the contribution of such investments to gross fixed capital formation is relatively small and so the pro-cyclical influence of having a common monetary policy via this sector of the economy is small as well. In 2005, for example, gross investment in manufacturing across the EU25 was five times greater than investment in construction and eight times greater than investment in hotels and restaurants (Eurostat). This is why economists spent little time worrying about local real interest rate differentials within national monetary unions before the single currency came about.

The housing market is a more important exception. First, housing is not subject to international arbitrage and so has to be discounted using local rates of inflation. Second, house price increases are often the major motivation behind making a housing investment. Put another way, home ownership is a form of savings (or deferred consumption). When house prices rise against a backdrop of fixed nominal interest rates, the build up of pressure in the housing market can be immense. The temptation to refinance and use home equity for current consumption can be immense as well. In this sense it is true that the common monetary policy fuels housing booms where they have started and deepens housing busts where they have already set in. Of course these developments in housing costs strengthen the counter-cyclical pattern of firm investment sketched above by raising or lowering the pressure on wages, but that is small consolation to those who find themselves unable to get on the property ladder or caught in a negative equity trap.

The question is whether separate national currencies and national monetary authorities are really the first best solution to address the problem of house-price speculation. This question is important but it is different from the more general consideration of stabilization and adjustment in a monetary union. With respect to stabilization and adjustment, the situation within the single currency is not so different from the state of affairs before the euro was introduced. Before the euro, exchange rates did not insulate countries from shocks because exchange rates are not determined in by the trade in goods and services, because firm-level exposure to foreign trade is not the same as national exposure, because exchange rate pairs are influenced by third currencies, and because many countries choose to fix exchange rates even outside the context of a monetary 
union. A more important change is the loss of autonomy over monetary policy. Even there, however, the effects are modest. Governments have lost some discretion in setting domestic interest rates. But those countries that joined the single currency gave up much of that monetary policy autonomy already when participating in the ERM. The irrevocable fixing of exchange rates eliminated the residual. Under the resulting common monetary policy, monetary conditions are not always the same across the member states and national central banks might opt for different conditions given the choice. Nevertheless, the influence of real interest rate differentials across countries is not as significant as some authors suggest.

\section{Fiscal Stabilization}

National fiscal authorities shoulder the major burden for macroeconomic stabilization in Europe's single currency-just as they did before the single currency was introduced. When countries suffer from an adverse shock, national fiscal authorities must act to mitigate the impact on unemployment. The difference under monetary union is two-fold. First, national fiscal authorities are constrained by the formal institutional commitments collected under the 'stability and growth pact' (SGP). Second, national fiscal authorities are empowered by the ease and low cost of sovereign borrowing and by the elimination of the balance of payments constraint.

The structure and influence of the SGP has received extensive coverage in the literature. The failure of the member states to abide by their commitments has received extensive coverage as well. At this point it is clear that the rules function only insofar as the member states agree to comply. This is bad news in terms of fiscal consolidation but it is good news for fiscal stabilization-at least in the short term. Those countries that suffered the worst of the recession of 2001-2003 could at least benefit from fiscal stimulus. This can be seen in Figure 3, which shows output growth and deficit performance for the euro-zone as a whole. In aggregate terms, as growth declined, fiscal deficits increased. This pattern primarily results from the automatic stabilization provided via taxes and transfers. When income falls, taxes fall as well and when unemployment rises transfers increase. This did not require a positive decision by policymakers to stimulate their economies but it did require a decision not to cut deficits pro-cyclically by restricting expenditure during the economic downturn. The results are better than critics of the SGP expected-more because of the advantages of already having undertaken a significant debt consolidation in order to join the monetary union rather than as a result of a repudiation of the Pact. Indeed, there was evidence that fiscal policy had become more effectively counter-cyclical even before the SGP broke down (Galí and Perotti 2003).

Insert Figure 3 about here.

The empowering influence of the single currency is less well documented even if still widely understood. By lowering borrowing costs across the euro-zone as a whole, and in traditionally high inflation countries in particular, the single currency also lowered the cost of debt service and so freed up fiscal resources for debt consolidation, new expenditure, or tax relief. This reduction in interest payments was very important for highly indebted countries such as Italy, which saw the ratio of debt service to gross domestic product (GDP) fall from 13.1 percent in 1993 to 4.9 percent in 2005. Although voices at the European Commission and in the European Central Bank (ECB) have called for the whole of the windfall to be used for debt consolidation, most member states engaged in some combination of debt consolidation with higher spending and lower taxes.

The elimination of the balance of payments constraint is more striking. Absent the risk of currency crisis, the member states of the euro-zone are able to sustain important current account imbalances. This can be seen in Figure 4, which shows the unweighted standard deviation across member state current accounts as a percentage of GDP. The same figure also provide an unweighted average for current balances across the member states. While the average remains 
Figure 3: Euro-zone Growth and Deficit Performance

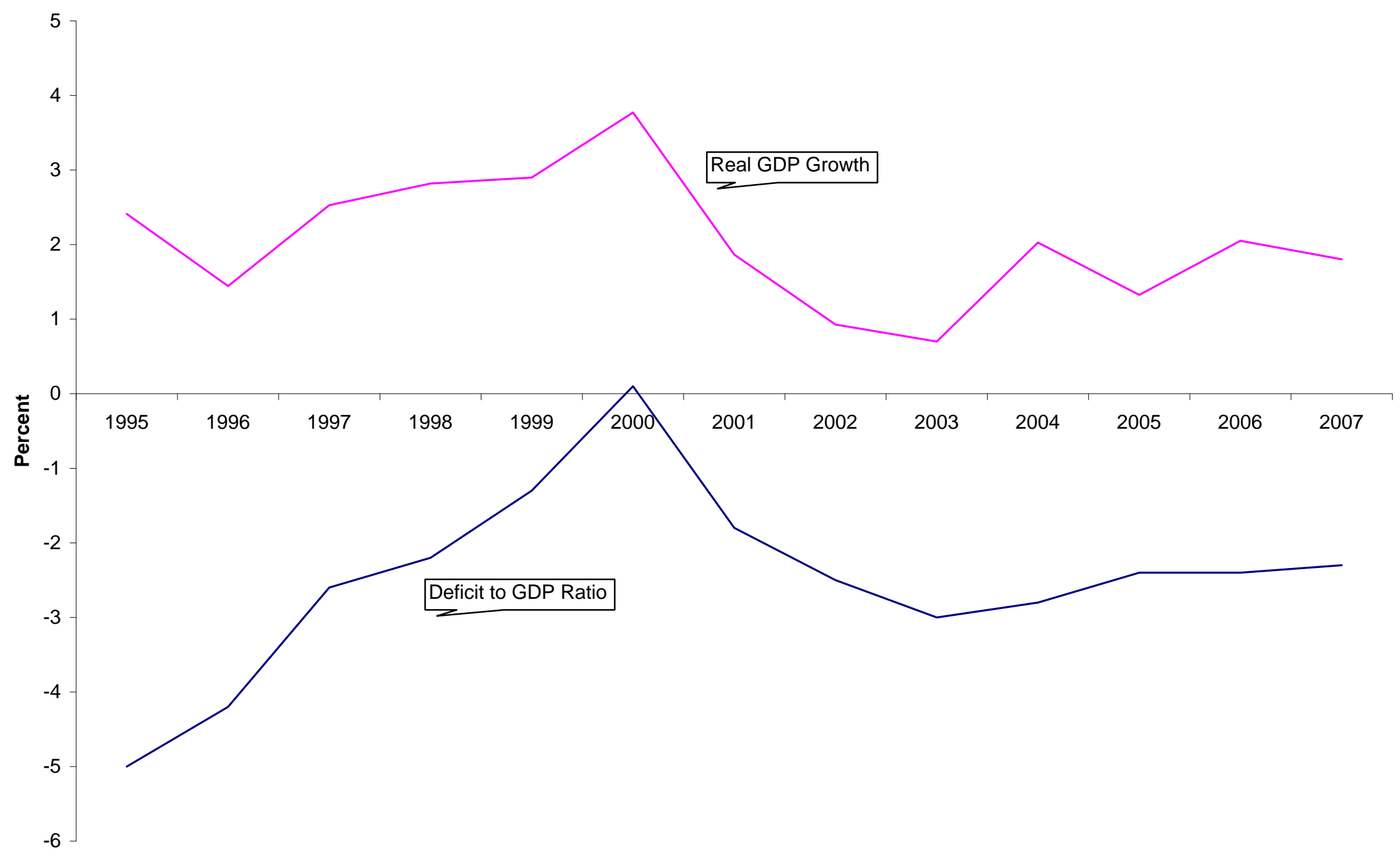


close to balance, the dispersion of member state performance has increased.

Insert Figure 4 about here.

This increased variation in current account performance is due in part to the variation in fiscal policy across the member states-not all of which is in response to the requirements for aggregate demand stabilization (Jones 2003). On the contrary, as performance in GDP growth has converged across the member states, deficit to GDP ratios have not. This pattern is in contrast to the run-up to the single currency when deficit performance was more strongly convergent (Hallerberg 2004). Developments since the introduction of the euro can be seen in Figure 5, which shows the standard deviation in real GDP growth rates and deficit to GDP levels across member states. The convergence in real GDP growth can be seen also in terms of unemployment levels. This is shown in Figure 6, which also includes the weighted and unweighted average rates of unemployment across the euro-zone.

Insert Figures 5 and 6 about here.

The point to note in looking across these figures is that those countries who have embraced the discipline of the stability and growth pact are not those countries that have had an easy time in terms of either growth or employment. On the contrary, the divisions that emerged in the Council of Economics and Finance Ministers (ECOFIN Council) when the Pact was set aside in November 2003 pit small countries against large more obviously than strong performers against weak ones. Indeed, the staunchest proponent of enforcing the rules, the Netherlands, soon found itself in violation of the SGP (Jones 2004: 493-495).

There are obvious reasons for small countries to want to have clear guidelines for fiscal policy while larger countries would want to have greater discretion. Moreover, these reasons are not dissimilar to original arguments about the characteristics of an optimum currency area (McKinnon 1963). Small countries tend to be more open to trade than larger countries as a percentage of income. As a result the impact of fiscal stimulus on a small country economy tends to bleed out across import consumption onto foreign markets, offering few significant advantages to their larger neighbors for the high fiscal cost of achieving any demand stimulus at home. By contrast, large countries tend to be more closed, meaning that domestic fiscal stimulus is more effective at generating domestic fiscal activity. Large countries are also more important to the economies of small countries than small countries are to the economies of large ones. Hence domestic stimulus in large countries offers significant advantages for their smaller neighbors; a failure to stimulate the large-country economy during a time of recession offers a significant downside as well. This asymmetry in economic interdependence is very well known (Cooper 1968). Nevertheless, the implication that different countries should have different fiscal rules has never been accepted in the European Union. Instead, Europe's heads of state and government have insisted that everyone be bound by the same framework-and then ignored that framework when it obviously did not make sense.

The reform of the SGP adopted in March 2005 continued along these lines and eschewed any categorical differentiation between member states in the handling of the rules. To my knowledge, no-one even raised the possibility that small countries and large countries should be given separate treatment. Instead, government representatives used large-country small-country distinctions as an implicit critique of the status quo. Hence, while the Council of Ministers endorsed a wider range of conditions in defining exceptional circumstances, these have more to do with historical factors like German unification than the logic of economic interdependence per se (Jones 2006). The result has been to decrease the importance of the rules per se and to strengthen the notion of national ownership or fiscal responsibility.

The new SGP is more flexible and-if past behavior is any guide to the future-the member states are willing to take advantage of that flexibility. The member states are also willing to take advantage of the low interest payments and light balance of payments constraint that the single 
Figure 4: Euro-zone Current Account Variability

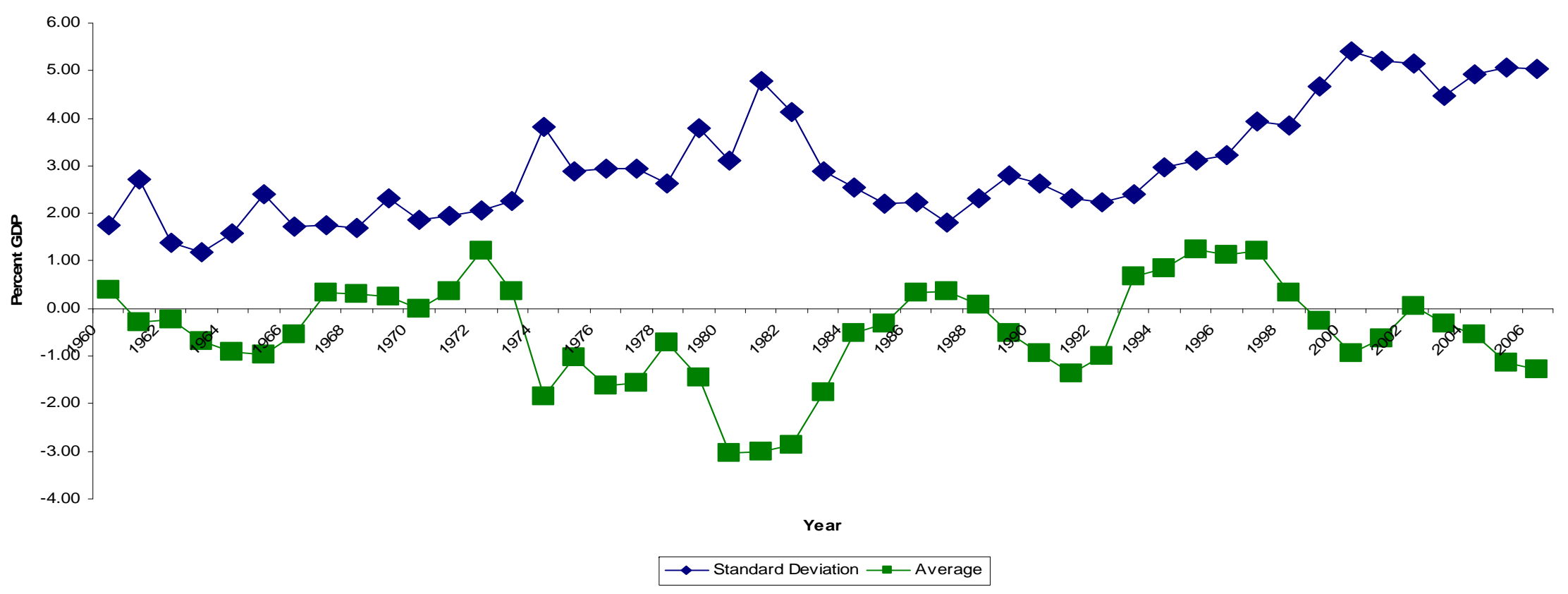


Figure 5: Convergence in Real GDP Growth and Government Deficits

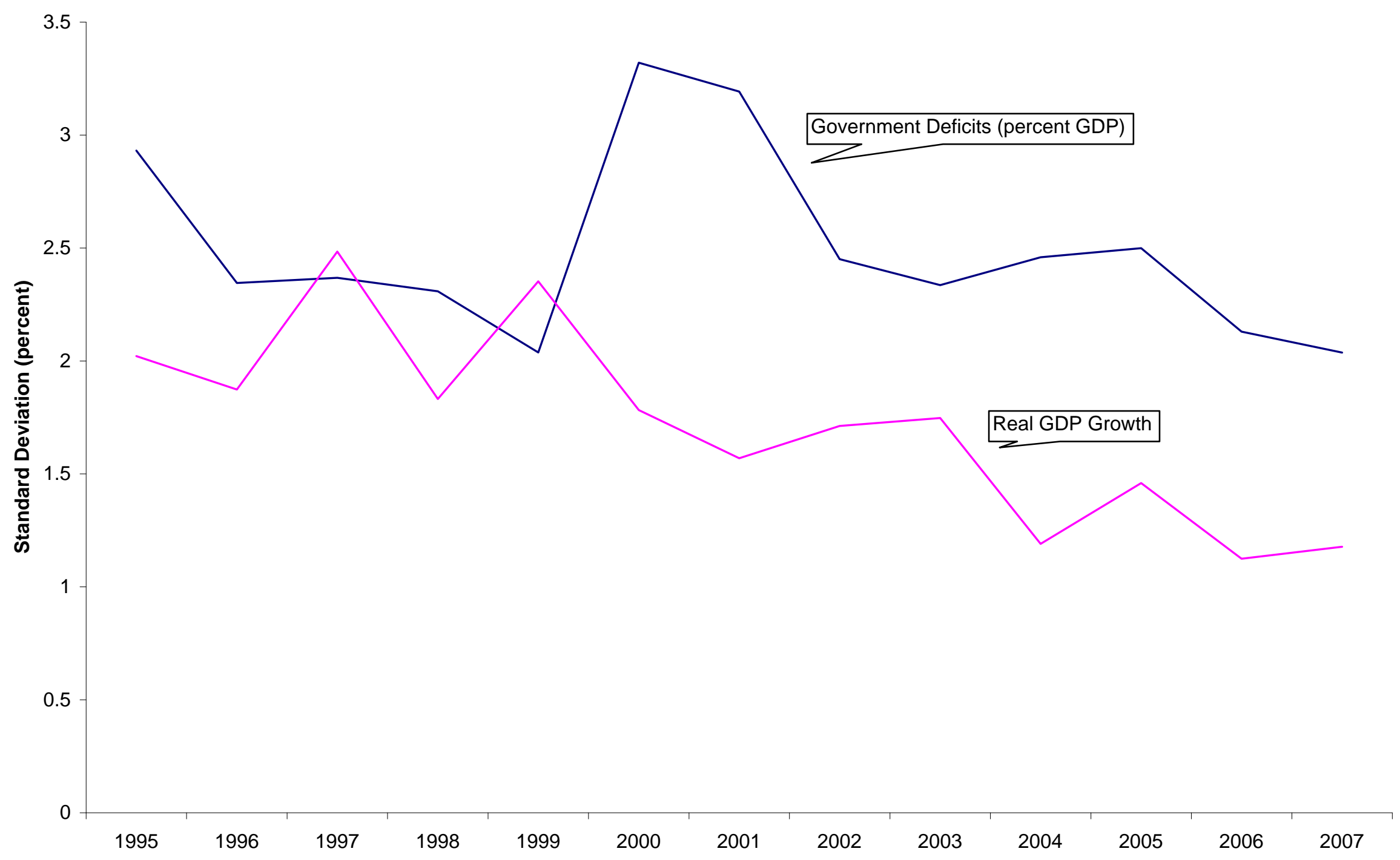


Figure 6: Unemployment Convergence

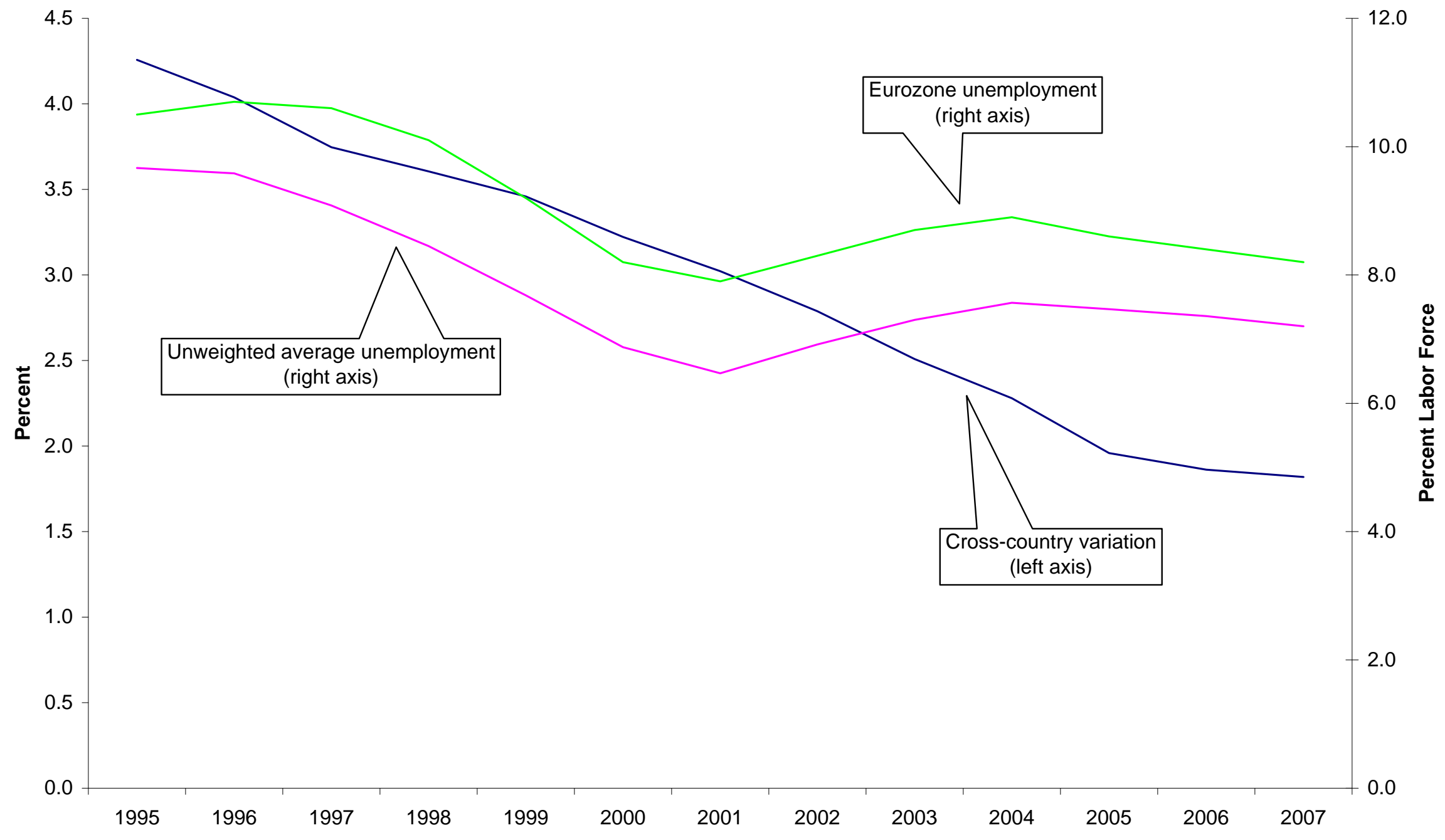


currency has brought about. The fact remains, however, that national fiscal authorities are not equally able to stabilize their economies using fiscal policy alone. Monetary policy is not available and exchange rates are irrevocably fixed. Although these latter constraints are not so burdensome as many believe, that does not make them politically palatable. Hence there is strong incentive to imagine institutions that can share the burdens of fiscal stabilization automatically from one member state to the next.

\section{International Fiscal Stabilization}

The belief that common fiscal institutions can provide stabilization across geographic regions (and therefore across member states) dates back to early debates about economic interdependence and optimum currency areas. Peter Kenen (1969) introduced the possibility in a 1967 conference paper and it was quickly picked up in work by Richard Cooper (1968: 19) and J. Marcus Fleming (1971: 478). By the end of the 1970s, the possibility of international fiscal stabilization even became part of the European Economic Community's plans to revitalize efforts at monetary integration in the "report of the study group on the role of public finance in European integration", also known as the McDougal report.

The argument for international fiscal stabilization is attractive because it follows the same pattern as the case for automatic fiscal stabilization within countries. When income falls, tax payments decline as well, thus absorbing some of the gross impact of the original shock. When unemployment rises, transfers also increase, thus cushioning the loss of income resulting from unemployment. The only difference between the international story and the national one is the pattern of income redistribution. In the national story, income is redistributed across time (through deficit spending) or across society (from haves to have nots). In the international story, income is redistributed across geographic space as well, with more prosperous regions implicitly transferring resources to less prosperous regions in response to the exogenous shock. Moreover, the scale of this stabilization is potentially significant-with recent estimates of the cushion provided by interregional stabilization within existing monetary union ranging from 10 to 30 percent of the shock (Sala-i-Martin and Sachs 1992; Bayoumi and Masson 1995; Mélitz and Zumer 1998; Mélitz 2004).

The only real complication in the argument is that the interregional dimension of the transfers is largely unintended. Apart from a few specialized arrangements, like the German system for Finanzausgleich between regional or Land governments, most federal fiscal systems provide inter-regional stabilization because they choose to monopolize control over income taxation and to standardize patterns of income replacement. Moreover, once the size of interregional transfers becomes politically significant, the tendency is to reduce the level of interregional redistribution rather than to celebrate it. Hence, for example, the German federal government had to absorb much of the cost of Finanzausgleich during the process of German unification because the western Länder were reluctant to make further additional transfers to the East. In the United States, transfers in aid to state and local government are usually provided on a matching basis-which has the perverse effect of benefitting rich parts of the country rather than poor.

The advocates of international fiscal stabilization are well aware of this contrary political logic. As Paul De Grauwe (2006) explains:

A warning note should be sounded here. When we argue that some form of budgetary centralization is necessary to allow for an insurance mechanism against asymmetric shocks, we should avoid the pitfalls of such mechanisms that have been observed within countries. These pitfalls have to do with moral hazard. We observe that this is often a serious problem when the transfers reduce the incentives of the receiving regions to adjust to shocks. As a result, temporary transfers can become chronic, thereby losing their insurance character. 
This feature will often lead to conflicts within the country (e.g. in Belgium) that are difficult to manage.

What they do not consider is that the standards for political significance are likely to change from one level of aggregation to the next. What passes for a reasonable level of redistribution in a closeknit society would not be tolerated in a larger group and would be actively opposed across different groups. The dilution of German Finanzausgleich illustrates this effect directly. It was not just the size of the transfers involved, but also the sense that the new Länder did not belong in the system.

There is an added problem. For any stabilization system to operate, there has to be a progressive and continuous redistribution of resources through taxes and transfers. This can be designed along mutually acceptable principles where those who have support those who have not. However, the stabilization takes place in response to a shock. The mechanism does not operate through income levels but rather through income changes. Hence if a wealthy country were to suffer an exogenous shock, part of the income lost by the wealthiest members of that society would be absorbed by declining tax outlays and part of the income lost by less wealthy members who are pushed into unemployment would be replaced by transfer payments. In interregional terms, this cushion would be provided by the poorer countries that did not suffer from the shock. In the most recent recession, Spain and Greece would have transferred resources to France and Germany.

The problem with this situation is two-fold. First, wealthy countries do not want to introduce progressive distributive mechanisms at the European level beyond those that already exist. Second, even if it were possible to introduce such mechanisms, the poorer member states would resent the implications should they actually work to stabilize income in response to exogenous shocks. Both parties would prefer to accept the risk that if something bad happens, they are on their own. And, as it happens, that is what they have got.

\section{Where Do We Go from Here?}

The status quo is not optimal, even if it is far from being as bad as many would like to believe. The reality is, however, that many of the alternatives are worse. A return to fixed but adjustable exchange rates would not improve the prospects for stabilization via currency movements and it would impose a considerable cost in terms of interest rates and balance of payments concerns on fiscal policymakers. Monetary policymakers would get back some room for maneuver in matching domestic interest rates to meet the needs of the non-traded service sector and the housing market, but only at the expense of higher borrowing costs across the economy as a whole. Policy response to exceptional circumstances would be marginally better, while normal conditions in the macroeconomy would be considerably worse.

The alternative of increasing the centralization of fiscal policy at the European level is equally unappealing. In order to prevent a political conflict that might arise if countries perceived themselves to be disadvantaged by the existence of the single currency and the conduct of the common monetary policy, we would be creating institutions that assign very transparent winners and losers across the member states. The cost of the European Union is already a push-button issue in the net-contributor countries when the total level of expenditure is around 1 percent of income. By increasing that figure we may be able to make the process of stabilization marginally better, but normal political conditions would be considerably worse.

The challenge in Europe is to get the right balance between unity and diversity, solidarity and independence. This is obvious (cliche even) but it is also instructive. Fixed exchange rates help, not because of the political symbolism of a common currency but because exchange rates were not floating freely in any event and they were imparting too many different shocks on different parts of the European economy. The common monetary policy is only a partial 
success-particularly with respect to housing bubbles. But that suggests that member states should use transaction taxes and capital gains rules to cool domestic housing markets in response to the monetary integration shock. Finally, it is clear (or at least should be clear) that treating economic policy as a matter of common interest does not entail every member state doing everything in the same way. France and Germany are more important as markets for other European importants; Greece and Portugal are more important as potential sources of default risk. Fiscal policy coordination should take these factors into account and not the requirements for stabilization per se. European fiscal policy involves many different countries with different needs and implications. That is the reality. By contrast, the problem of stabilization in response to asymmetric shocks is a myth. 


\section{References}

Bayoumi, Tamim, and Barry Eichengreen (1997). 'Ever Closer to Heaven? An Optimum-

Currency-Area Index for European Countries.’ European Economic Review 41, pp. 761-770.

Bayoumi, Tamim, and Barry Eichengreen (1998). 'Exchange Rate Volatility and Intervention: Implications of the Theory of Optimum Currency Areas.’ Journal of International Economics 45, pp. 191-209.

Bayoumi, Tamim, and Paul R. Masson (1995). 'Fiscal Flows in the United States and Canada: Lessons for Monetary Union in Europe.’ European Economic Review 39, pp. 253-274.

Cooper, Richard N. (1968). The Economics of Interdependence: Economic Policy in the Atlantic Community. New York: McGraw Hill for the Council on Foreign Relations.

De Grauwe, Paul (2006). 'Monetary Integration since the Maastricht Treaty.' Journal of Common Market Studies 44:4 (November) pp. 711-730.

Enderlein, Henrik (2006). 'Adjustment to EMU: The Impact of Supranational Monetary Policy on Domestic Fiscal and Wage-Setting Institutions.’ European Union Politics 7:1 (March) pp. 113140.

Fatás, Antonio (1998). 'Does EMU Need a Fiscal Federation?’. In David Begg, Jürgen von Hagen, Charles Wyplosz, and Kaus F. Zimmermann, eds. EMU: Prospects and Challenges for the Euro. Oxford: Blackwell, pp. 163-192.

Fleming, J. Marcus (1971). 'On Exchange Rate Unification.’ The Economic Journal 81:323 (September) pp. 467-488.

Galí, Jordi, and Roberto Perotti (2003). 'Fiscal Politics and Monetary Integration in Europe.’ In Richard Baldwin, Guiseppe Bertola, and Paul Seabright, eds. EMU: Assessing the Impact of the Euro. Oxford: Blackwell, pp. 241-272.

Goodhart, C.A.E. (2006). 'The ECB and the Conduct of Monetary Policy.' Journal of Common Market Studies 44:4 (November) pp. 757-778.

Gowa, Joanne, and Edward D. Mansfield (2004). 'Alliances, Imperfect Markets, and Major-Power Trade.’ International Organization 58, pp. 775-805.

Jones, Erik (2003). 'Liberalized Capital Markets, State Autonomy, and European Monetary Union.’ European Journal of Political Research 42:2 (March) pp. 111-136.

Jones, Erik (2004). 'The Politics of Europe 2003: Differences and Disagreements.' Industrial Relations Journal 35:6 (November) pp. 483-499.

Jones, Erik (2006). 'European Macroeconomic Governance.’ In Jeremy Richardson, ed. European Union Power and Policymaking, Third Edition. London: Routledge, pp. 329-349.

Hallerberg, Mark (2004). Domestic Budgets in a United Europe: Fiscal Governance from the End 
of the Bretton Woods System to EMU. Ithaca and London: Cornell University Press.

Kavanagh, Ella, et al. (1998). 'The Political Economy of EMU in Ireland.' In Erik Jones, Jeffrey Frieden, and Francisco Torres, eds. Joining Europe's Monetary Club: The Challenges for Smaller Member States. New York: St. Martin’s Press, pp. 123-148.

Kenen, Peter B. (1969). 'The Theory of Optimum Currency Areas: An Eclectic View.' In Robert A. Mundell and Alexander K. Swoboda, eds. Monetary Problems of the International Economy. Chicago: University of Chicago Press, pp. 41-60.

McKinnon, Ronald I. (1963). 'Optimum Currency Areas.' American Economic Review 53:4 (September) pp. 717-725.

Mélitz, Jacques (2004). 'Risk Sharing and EMU.’ Journal of Common Market Studies 42:4 (November) pp. 815-840.

Mélitz, Jacques, and Frédéric Zumer (1998). 'Redistribution régionale et stabilisation par le gouvernement central.’ Economie Internationale 75:3, pp. 3-31.

Mundell, Robert A. (1973). ‘Uncommon Arguments for Common Currencies.’ In Harry G. Johnson and Alexander K. Swoboda, eds. The Economics of Common Currencies. London: George Allen and Unwin Ltd., pp. 114-132.

Sadeh, Tal (2005). 'Who Can Adjust to the Euro?’ The World Economy 28:11 (November) pp. 1651-1678.

Sadeh, Tal (2006a). 'Adjusting to EMU: Electoral, Partisan, and Fiscal Cycles.' European Union Politics 7:3 (September) pp. 347-372.

Sadeh, Tal (2006b). Sustaining European Monetary Union: Confronting the Cost of Diversity. Boulder: Lynne Reinner.

Sala-i-Martin, Xavier, and Jeffrey Sachs (1992). 'Fiscal Federalism and Optimum Currency Areas: Evidence for Europe from the United States.' In Mathew B. Canzonieri, Vittorio Grilli, and Paul R. Masson, eds. Establishing a Central Bank: Issues in Europe and Lessons from the United States. Cambridge: Cambridge University Press, pp. 195-219.

Steil, Benn (2007). 'The End of National Currency.' Foreign Affairs 86:3 (May/June) pp. 83-96.

Tamborini, Roberto (2006). 'The "Brussels Consensus” on Macroeconomic Stabilization Policies in EMU: A Critical Assessment.' In Francisco Torres, Amy Verdun, and Hubert Zimmermann, eds. EMU Rules: The Political and Economics Consequences of European Monetary Integration. Baden-Baden: Nomos Verlagsgesellschaft, pp. 137-159.

Tavlas, George S. (1993). 'The “New” Theory of Optimum Currency Areas.' The World Economy 16:6 (November) pp. 663-685.

Tsoukalis, Loukas (2005). What Kind of Europe? Updated and Expanded Edition. Oxford: Oxford University Press. 